CLINICAL STUDY

\title{
Serum levels of adipocyte fatty acid binding protein are increased in gestational diabetes mellitus
}

\author{
Susan Kralisch ${ }^{1,2}$, Holger Stepan ${ }^{3}$, Jürgen Kratzsch ${ }^{4}$, Michael Verlohren ${ }^{5}$, Hans-Joachim Verlohren ${ }^{5}$, \\ Kathrin Drynda $^{6}$, Ulrike Lössner ${ }^{1}$, Matthias Blüher ${ }^{1}$, Michael Stumvoll ${ }^{1}$ and Mathias Fasshauer ${ }^{1,2}$ \\ ${ }^{1}$ Department of Internal Medicine III, University of Leipzig, Ph.-Rosenthal-Street 27, 04103 Leipzig, Germany, ${ }^{2}$ Interdisciplinary Center for Clinical \\ Research (IZKF) Leipzig, 04103 Leipzig, Germany, ${ }^{3}$ Department of Obstetrics, University of Leipzig, 04103 Leipzig, Germany ${ }^{4}$ Institute of Laboratory \\ Medicine, University of Leipzig, 04103 Leipzig, Germany, ${ }^{5}$ Outpatient Care Unit, 04177 Leipzig, Germany and ${ }^{6}$ Outpatient Care Unit, 04103 Leipzig, \\ Germany \\ (Correspondence should be addressed to M Fasshauer; Email: mathias.fasshauer@medizin.uni-leipzig.de)
}

\begin{abstract}
Objective: Adipocyte fatty acid binding protein (AFABP) was recently introduced as a novel adipokine, serum levels of which independently correlate with the development of the metabolic syndrome and cardiovascular disease in humans. In the current study, we investigated serum concentrations of AFABP in patients with gestational diabetes mellitus (GDM) as compared with healthy pregnant controls matched for gestational age and fasting insulin.

Design and methods: AFABP was determined by ELISA in controls $(n=80)$ and GDM patients $(n=40)$ and correlated to clinical and biochemical measures of renal function, glucose and lipid metabolism, as well as inflammation, in both groups.

Results: Median serum AFABP concentrations were significantly elevated in subjects with GDM $(22.9 \mu \mathrm{g} / \mathrm{l})$ as compared with healthy pregnant controls $(18.3 \mu \mathrm{g} / \mathrm{l} ; \mathrm{P}<0.05)$. Furthermore, GDM was independently associated with AFABP concentrations in multiple regression analysis $(P<0.05)$. In addition, markers of adiposity (body mass index, serum leptin), triglycerides and serum creatinine were independently associated with circulating AFABP $(P<0.05)$.

Conclusions: Maternal AFABP concentrations are significantly increased in GDM. The adipokine might contribute to the increased metabolic and cardiovascular risk of the disease.
\end{abstract}

European Journal of Endocrinology $16033-38$

\section{Introduction}

Gestational diabetes mellitus (GDM) is a serious complication in pregnancy that is characterized by glucose intolerance with onset or first recognition during pregnancy (1). As a consequence of a diabetic pregnancy, mother and newborn have a significantly increased future risk of metabolic and cardiovascular diseases. Thus, the 8 year post partum diabetes mellitus risk was $>50 \%$ in patients with previous GDM (2). Furthermore, cardiovascular risk factors including intima-media thickness (IMT), circulating levels of E-selectin, and intercellular adhesion molecule-1 were significantly increased in previous GDM patients 6.5 years after delivery as compared with controls (3).

The pathogenetic mechanisms underlying GDM have been better elucidated in recent years and are similar to obesity-associated type 2 diabetes mellitus (T2DM). Thus, insulin resistance during pregnancy and a limitation in the pancreatic $\beta$-cell reserve contribute to the development of the disease. Furthermore, adipocyte-secreted factors - so-called adipokines - that influence insulin sensitivity might play an important role in the pathogenesis of GDM. Here, decreased levels of the insulin-sensitizing and vasoprotective adipokine adiponectin have been found in GDM in several independent studies (4-6). Furthermore, adiponectin was lower in women in early pregnancy who later developed GDM (7). Interestingly, a positive association between circulating adiponectin and $\beta$-cell function existed in pregnant women (8). Studies on regulation of the appetitesuppressive adipokine leptin in GDM have been less clear. Thus, increased serum levels of leptin during early pregnancy predicted the clinical onset of GDM $(9,10)$. By contrast, women with mild GDM presented with relative hypoleptinaemia as compared with controls in another study (11). Furthermore, leptin administration prevented spontaneous GDM in heterozygous leptin receptordeficient mice (12).

Adipocyte fatty acid binding protein (AFABP, also known as aP2 and FABP4) has recently been described as a novel adipokine associated with insulin resistance, T2DM, and cardiovascular disease. Thus, AFABP serum levels were significantly increased in overweight and obese subjects as compared with lean controls and correlated positively with waist circumference, blood 
pressure, and insulin resistance (13). Higher baseline levels of circulating AFABP independently predicted the risk to develop a metabolic syndrome during a follow-up of 5 years (14). Similarly, baseline AFABP concentrations were predictive of T2DM independent of obesity, insulin resistance or glycemic indexes (15). Work from the same group showed that serum AFABP levels were positively linked with carotid IMT and presence of plaques in women (16). These results indicate that AFABP might have a central role in the development of metabolic and cardiovascular disease.

By contrast to adipokines including adiponectin and leptin, AFABP serum concentrations have not been evaluated so far in GDM. In the current study, we therefore, sought to investigate for the first time whether maternal AFABP levels are altered in GDM and might potentially contribute to the present and future metabolic and cardiovascular risk of the disease. We determined AFABP levels in 80 control and 40 GDM patients who were matched for gestational age and fasting insulin (FI) and correlated serum concentrations of this adipocyte-expressed factor to clinical and biochemical measures of renal function, glucose and lipid metabolism, as well as inflammation.

\section{Subjects and methods}

\section{Subjects}

Forty pregnant women with GDM and eighty controls matched for gestational age and FI were recruited. GDM was diagnosed if one or more plasma glucose levels were elevated during a $75 \mathrm{~g}, 2 \mathrm{~h}$ oral glucose tolerance test (OGTT) according to the criteria of the Austrian Diabetes Association (17). The following threshold plasma glucose levels were used: fasting $\geq 5.3 \mathrm{mmol} / \mathrm{l}$; $1 \mathrm{~h} \geq 10.0 \mathrm{mmol} / \mathrm{l} ; 2 \mathrm{~h} \geq 8.6 \mathrm{mmol} / \mathrm{l}$ (17). Body mass index (BMI) was calculated as weight before pregnancy divided by squared height. Age of the patients ranged from 18 to 45 years and BMI from 15.6 to $38.2 \mathrm{~kg} / \mathrm{m}^{2}$. Homeostasis model assessment of insulin resistance (HOMA-IR) was calculated as previously described (18). Patients with renal diseases, preeclampsia, and generalized inflammation were excluded from the study. The study protocol was approved by the local Ethics Committee. All patients gave written informed consent before taking part in the study.

\section{Assays}

Blood samples were taken after an overnight fast. At the time of the blood sampling, none of the women was in labor. Serum insulin was determined with a two-site chemiluminescent enzyme immunometric assay for the Immulite automated analyzer (Diagnostic Products, Los Angeles, CA, USA). AFABP (Biovendor, Modrice, Czech Republic), adiponectin, resistin, and leptin (all
Mediagnost, Reutlingen, Germany) were determined with ELISAs according to the manufacturers' instructions. Serum creatinine, cholesterol, triglycerides (TG), and $\mathrm{C}$ reactive protein $(\mathrm{CRP})$ were measured by standard laboratory methods in a certified laboratory.

\section{Statistical analysis}

SPSS software version 11.5 (SPSS, Chicago, IL, USA) was used in all statistical analyses. Differences between controls and GDM patients were assessed by MannWhitney- $U$ test. Correlations were performed using the Spearman's rank correlation method. To adjust the effects of covariates and identify independent relationships, multivariate linear regression analyses were performed. Before performing multivariate analyses, distribution was tested for normality using ShapiroWilk $W$ test and non-normally distributed parameters were logarithmically transformed. A $P$-value of $<0.05$ was considered as statistically significant in all analyses.

\section{Results}

\section{AFABP serum levels are increased in GDM patients as compared with controls}

Table 1 summarizes the clinical characteristics of the subgroups studied (Control, GDM). All continuous variables are given as median \pm interquartile range. Maternal serum AFABP concentrations were significantly elevated in

Table 1 Baseline characteristics of the study population.

\begin{tabular}{|c|c|c|}
\hline & Control & GDM \\
\hline$N$ & 80 & 40 \\
\hline $\operatorname{AFABP}(\mu \mathrm{g} / \mathrm{l})$ & $18.3 \pm 12.9$ & $22.9 \pm 12.2^{\star}$ \\
\hline Age (years) & $28 \pm 5$ & $33 \pm 10^{*}$ \\
\hline BMI $\left(\mathrm{kg} / \mathrm{m}^{2}\right)$ & $22 . \overline{3} \pm 7.0$ & $24 . \overline{9} \pm 4.9$ \\
\hline $\mathrm{SBP}(\mathrm{mmHg})$ & $125 \pm 16$ & $121 \pm 23$ \\
\hline $\mathrm{DBP}(\mathrm{mmHg})$ & $75 \pm 13$ & $71 \pm 17$ \\
\hline $\begin{array}{l}\text { Gestational age at blood } \\
\text { sampling (days) }\end{array}$ & $198 \pm 39$ & $205 \pm 30$ \\
\hline Glucose $0 \mathrm{~h}(\mathrm{mmol} / \mathrm{l})$ & $4.2 \pm 0.4$ & $4.5 \pm 0.9^{*}$ \\
\hline Glucose $1 \mathrm{~h}$ (mmol/l) & $7.5 \pm 1.6$ & $10.3 \pm 1.6^{*}$ \\
\hline Glucose $2 \mathrm{~h}$ (mmol/l) & $6.2 \pm 1.8$ & $9.0 \pm 2.3^{*}$ \\
\hline $\mathrm{FI}(\mathrm{pmol} / \mathrm{l})$ & $56 . \overline{5} \pm 39.3$ & $60 . \overline{3} \pm 37.1$ \\
\hline HOMA-IR & $1.4 \pm 1.0$ & $1.6 \pm 1.3$ \\
\hline Creatinine $(\mu \mathrm{mol} / \mathrm{l})$ & $49 \pm 12$ & $46 \pm 11$ \\
\hline $\mathrm{TG}(\mathrm{mmol} / \mathrm{l})$ & $2.1 \pm 1.4$ & $2.2 \pm 1.3$ \\
\hline Cholesterol $(\mathrm{mmol} / \mathrm{l})$ & $6.3 \pm 1.8$ & $6.6 \pm 2.2$ \\
\hline HDL cholesterol (mmol/l) & $1.9 \pm 0.5$ & $1.7 \pm 0.7$ \\
\hline LDL cholesterol (mmol/l) & $3.7 \pm 1.6$ & $3.8 \pm 1.9$ \\
\hline Leptin $(\mu \mathrm{g} / \mathrm{l})$ & $23 . \overline{1} \pm 11.7$ & $24.9 \pm 13.9$ \\
\hline Adiponectin (mg/l) & $7.0 \pm 3.9$ & $7.3 \pm 5.6$ \\
\hline Resistin $(\mu \mathrm{g} / \mathrm{l})$ & $7.4 \pm 4.5$ & $6.5 \pm 3.6$ \\
\hline $\mathrm{CRP}(\mathrm{mg} / \mathrm{l})$ & $4.3 \pm 4.5$ & $4.2 \pm 4.9$ \\
\hline
\end{tabular}

AFABP, adipocyte fatty acid binding protein; BMI, body mass index; CRP, C reactive protein; DBP, diastolic blood pressure; FI, fasting insulin; GDM, gestational diabetes mellitus; HDL, high-density lipoprotein; HOMA-IR, homeostasis model assessment of insulin resistance; LDL, low-density lipoprotein; SBP, systolic blood pressure and TG, triglycerides. Values for median \pm interquartile range are shown. ${ }^{*} P<0.05$ as compared to control as assessed by Mann-Whitney- $U$ test. 
subjects with GDM $(22.9 \pm 12.2 \mu \mathrm{g} / \mathrm{l})$ as compared with healthy pregnant controls $(18.3 \pm 12.9 \mu \mathrm{g} / \mathrm{l} ; \quad P<0.05$; Table 1). Furthermore, AFABP levels were significantly higher in overweight-obese (BMI $\geq 25 \mathrm{~kg} / \mathrm{m}^{2}, 22.4 \pm$ $15.3 \mu \mathrm{g} / \mathrm{l})$ as compared with lean (BMI $<25 \mathrm{~kg} / \mathrm{m}^{2}$, $15.3 \pm 11.2 \mu \mathrm{g} / \mathrm{l})$ controls $(P<0.001$; Fig. 1). Patients with GDM were significantly older $(33 \pm 10$ years $)$ as compared with control subjects $(28 \pm 5$ years; $P<0.05$; Table 1). However, the significant difference in AFABP serum levels between GDM and control patients persisted after adjustment for maternal age $(P<0.05$; data not shown). Both groups were matched for FI $(60.3 \pm 37.1$ vs $56.5 \pm 39.3 \mathrm{pmol} / \mathrm{l})$ and gestational age at blood sampling

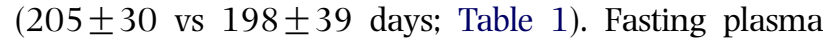
glucose, as well as 1 and $2 \mathrm{~h}$ glucose values during $75 \mathrm{~g}$ OGTT were significantly higher in GDM patients as compared with controls $(P<0.001$; Table 1$)$. By contrast, BMI, as well as markers of lipid metabolism (TG, cholesterol), inflammation (CRP), and renal function (creatinine) were not significantly different between the two groups (Table 1).

\section{Univariate correlations}

Serum AFABP levels positively correlated with BMI, systolic blood pressure (SBP), FI, HOMA-IR, creatinine, TG, leptin, and CRP $(P<0.05$; Table 2$)$. By contrast, AFABP concentrations did not show an association with age, diastolic blood pressure, gestational age at blood sampling, fasting glucose, 1 and $2 \mathrm{~h}$ glucose during $75 \mathrm{~g}$ OGTT, cholesterol, resistin, and adiponectin (Table 2).

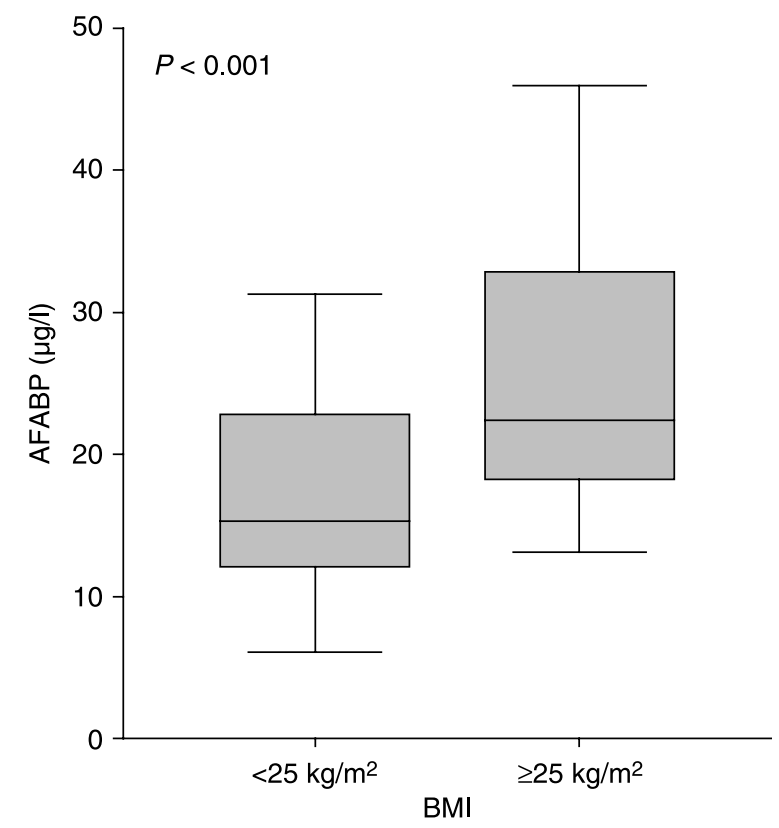

Figure 1 AFABP serum levels in lean $\left(B M I<25 \mathrm{~kg} / \mathrm{m}^{2}\right)$ and overweight/obese $\left(\mathrm{BMI} \geq 25 \mathrm{~kg} / \mathrm{m}^{2}\right)$ pregnant controls. Boxplot graphs are shown. Differences between the two groups were analyzed by Mann-Whitney- $U$ test.
Table 2 Univariate correlations with serum adipocyte fatty acid binding protein (AFABP) concentrations.

\begin{tabular}{|c|c|c|}
\hline & $\boldsymbol{r}$ & $\boldsymbol{P}$ \\
\hline Age (years) & 0.139 & 0.129 \\
\hline BMI $\left(\mathrm{kg} / \mathrm{m}^{2}\right)$ & 0.519 & $<0.001^{\star}$ \\
\hline $\mathrm{SBP}(\mathrm{mmHg})$ & 0.191 & $0.040^{\star}$ \\
\hline $\mathrm{DBP}(\mathrm{mmHg})$ & 0.133 & 0.157 \\
\hline $\begin{array}{l}\text { Gestational age at blood } \\
\text { sampling (days) }\end{array}$ & 0.175 & 0.059 \\
\hline Glucose $0 \mathrm{~h}(\mathrm{mmol} / \mathrm{l})$ & 0.129 & 0.163 \\
\hline Glucose $1 \mathrm{~h}(\mathrm{mmol} / \mathrm{l})$ & 0.171 & 0.070 \\
\hline Glucose $2 \mathrm{~h}(\mathrm{mmol} / \mathrm{l})$ & 0.037 & 0.699 \\
\hline $\mathrm{FI}(\mathrm{pmol} / \mathrm{l})$ & 0.266 & $0.004^{*}$ \\
\hline HOMA-IR & 0.264 & $0.004^{*}$ \\
\hline Creatinine $(\mu \mathrm{mol} / \mathrm{l})$ & 0.235 & $0.010^{\star}$ \\
\hline $\mathrm{TG}(\mathrm{mmol} / \mathrm{l})$ & 0.345 & $<0.001^{\star}$ \\
\hline Cholesterol (mmol/l) & 0.111 & 0.230 \\
\hline HDL cholesterol (mmol/l) & -0.090 & 0.328 \\
\hline LDL cholesterol (mmol/l) & 0.060 & 0.518 \\
\hline Leptin $(\mu \mathrm{g} / \mathrm{l})$ & 0.437 & $<0.001^{*}$ \\
\hline Adiponectin (mg/l) & -0.107 & 0.244 \\
\hline Resistin $(\mu \mathrm{g} / \mathrm{l})$ & -0.009 & 0.926 \\
\hline CRP (mg/l) & 0.201 & $0.031^{*}$ \\
\hline
\end{tabular}

$r$ - and $P$-values are given. Abbreviations are indicated in Table 1. * Significant correlation as assessed by Spearman's correlation method.

\section{Multivariate correlations}

In multiple regression analysis, the positive association between AFABP serum concentrations on one hand and BMI, creatinine, and TG on the other hand persisted after adjustment for SBP, HOMA-IR, and CRP (Table 3, model 1). When circulating leptin instead of BMI and FI instead of HOMA-IR were included in multivariate analysis, leptin but not FI remained independently associated with serum AFABP concentrations (Table 3,

Table 3 Multivariate linear regression analyses between adipocyte fatty acid binding protein (AFABP; dependent variable) and body mass index (BMI), systolic blood pressure (SBP), homeostasis model assessment of insulin resistance (HOMA-IR), creatinine, triglycerides (TG), C reactive protein (CRP), and gestational diabetes mellitus (GDM; Model 1), as well as between AFABP (dependent variable) and leptin, SBP, fasting insulin (FI), creatinine, TG, CRP, and GDM (Model 2).

\begin{tabular}{llcc}
\hline Model & $\begin{array}{c}\text { Independent } \\
\text { variable }\end{array}$ & $\boldsymbol{\beta}$ & $\boldsymbol{P}$ \\
\hline Model 1 & BMI & 0.317 & $0.001^{*}$ \\
& SBP & 0.040 & 0.645 \\
& HOMA-IR & 0.155 & 0.107 \\
& Creatinine & 0.346 & $<0.001^{*}$ \\
& TG & 0.232 & $0.006^{*}$ \\
& GRP & 0.056 & 0.481 \\
Model 2 & GDM & 0.165 & $0.042^{*}$ \\
& Leptin & 0.259 & $0.008^{*}$ \\
& SBP & 0.098 & 0.259 \\
& FI & 0.067 & 0.510 \\
& Creatinine & 0.306 & $<0.001^{*}$ \\
& TG & 0.259 & $0.003^{*}$ \\
& GRP & 0.065 & 0.427 \\
& GDM & 0.230 & $0.005^{*}$ \\
\hline
\end{tabular}

$\beta$-coefficients and $P$-values are given, * indicates significant correlation. 
model 2). GDM remained significantly correlated with serum AFABP levels independent of BMI/leptin, SBP, HOMA-IR/FI, creatinine, TG, and CRP in multivariate analyses (Table 3).

\section{Discussion}

In the current study, we demonstrate for the first time that maternal-serum levels of the adipokine AFABP are significantly increased in GDM patients as compared with healthy pregnant controls who are matched for gestational age and FI. Moreover, GDM remains significantly associated with serum AFABP concentrations independent of markers of adiposity (BMI, leptin), insulin resistance (FI, HOMA-IR), TG, CRP, and serum creatinine. Three recent well-controlled studies demonstrate that AFABP serum levels independently predict the risk to develop a metabolic syndrome (14), as well as T2DM (15), and are independently related to IMT in women (16). Furthermore, several independent studies in animals and humans indicate that AFABP is not only related to metabolic and cardiovascular disease but also directly promotes these conditions. Thus, targeted ablation of AFABP protects mice from obesityassociated insulin resistance and T2DM (19). AFABPdeficient $\mathrm{ob}-\mathrm{ob}$ mice are more insulin-sensitive compared with controls and show lower plasma glucose and insulin levels, better performance in insulin and glucose tolerance tests, as well as lower plasma TG and cholesterol concentrations (20). AFABP ablation in ApoE-knockout mice significantly reduces mean atherosclerotic lesion size in the proximal aorta as compared with ApoE-deficient controls $(21,22)$. These proatherogenic effects of AFABP appear to be mediated via direct actions in macrophages, through modification of cholesterol trafficking, and through activation of inflammatory signaling molecules including nuclear factor $\kappa \mathrm{B}(23)$. AFABP inhibition by the orally active small-molecule inhibitor BMS309403 in mice reduces the extent of atherosclerotic lesion area in the proximal aorta (24). Furthermore, this AFABP inhibitor decreases blood glucose and insulin levels and increases concentrations of the insulin-sensitizing adipokine adiponectin in ob-ob mice (24). In humans, subjects with a functionally significant genetic variation of the AFABP locus leading to decreased adipose tissue AFABP expression have lower TG levels, as well as a significantly reduced risk for coronary heart disease and T2DM (25). In agreement with these findings, lower expression of AFABP is found in adipose tissue of lean and weight-reduced individuals as compared with obese subjects (26). Taking these studies into consideration, increased AFABP concentration in GDM might contribute to the increased metabolic and cardiovascular risk of the disease. It needs to be tested in future studies whether increased AFABP levels persist in GDM patients after delivery.
In the current study, we demonstrate that markers of adiposity (BMI, leptin) are independently correlated with serum AFABP levels. These findings support previous data from our group showing an independent association between AFABP and BMI in a study with preeclamptic patients (27). A similar association has also been shown in several non-pregnant populations. Thus, baseline age- and sex-adjusted serum AFABP concentrations correlate with BMI after 5-year followup in 495 non-diabetic adults (14). Similarly, circulating AFABP levels are correlated with BMI in 67 nonobese and healthy subjects and 71 patients with the metabolic syndrome (28). Furthermore, AFABP concentrations are significantly associated with BMI before and 6 months after gastric banding in 33 morbidly obese patients (29). In addition, we have recently shown that BMI is independently correlated with circulating AFABP in patients on chronic hemodialysis (30). Taking this published evidence into consideration, circulating AFABP appears to be regulated in a body weightdependent manner similar to the adipokine leptin. It is tempting to speculate that hyperplastic and hypertrophic fat tissue developing during weight gain directly leads to increased AFABP production. In accordance with this hypothesis, serum AFABP levels closely and positively correlate with AFABP synthesis in adipose tissue (14).

In the current study, we demonstrate that renal function assessed as serum creatinine is strongly and independently correlated with circulating AFABP concentrations. These findings are in accordance with previous data from our group showing that serum creatinine and AFABP are independently associated in preeclampsia (27). Furthermore, we have recently demonstrated that AFABP is more than ten-fold higher in patients on chronic hemodialysis as compared with controls (30). These results further support the notion that renal elimination is a major route by which physiological AFABP serum levels are maintained. In addition, markers of renal function should always be included in studies concerning AFABP physiology and regulation.

In our study, BMI is not significantly different between GDM patients and controls, whereas increased body weight in GDM has been described by various groups $(4$, 31 , 32). However, GDM patients and controls are matched for FI as a marker of insulin resistance in our study, whereas FI has been increased in GDM patients $(4,32)$ or has not been determined (31) previously. It is well established that FI increases when body weight is gained. Taking these facts into consideration, it appears plausible that BMI is not significantly different between controls and GDM patients in our study since both groups are matched for FI.

Furthermore, downregulation of the insulin-sensitizing adipokine adiponectin has recently been shown in GDM $(4-6,31,32)$ in contrast to our current results. Again, these different findings are most probably due to 
the fact that insulin resistance was similar in GDM and control patients in our study in contrast to previous reports $(4-6,31,32)$. Similar to adiponectin, serum resistin levels are not significantly different between GDM and control patients in our hands. It is interesting to note in this context that both upregulation (33) and downregulation (34) of this adipokine in GDM have been described recently.

Some limitations of the present study have to be pointed out: first, cross-sectional data are presented and the sample size is relatively small. Furthermore, we cannot exclude the possibility that confounding factors that influence circulating AFABP have not been considered.

Taken together, we present evidence that maternal AFABP levels are significantly increased in GDM which might contribute to increased metabolic and cardiovascular risk in these patients. Furthermore, we show that body weight, renal function, and TG are independently associated with serum AFABP concentrations. More work is needed to better elucidate the mechanisms by which circulating AFABP influences metabolic and cardiovascular health.

\section{Declaration of interest}

There is no conflict of interest that could be perceived as prejudicing the impartiality of the research reported.

\section{Funding}

This study was supported by a grant from the Deutsche Forschungsgemeinschaft (DFG), KFO 152: 'Atherobesity', project FA476/4-1 (TP 4) to M.F., project BL833/1-1 (TP3) to M.B., the IZKF Leipzig to M.F. (Project B25), and the Deutsche Diabetes Gesellschaft (DDG) to S.K.

\section{References}

1 Buchanan TA, Xiang A, Kjos SL \& Watanabe R. What is gestational diabetes? Diabetes Care 200730 S105-S111.

2 Lobner K, Knopff A, Baumgarten A, Mollenhauer U, Marienfeld S, Garrido-Franco M, Bonifacio E \& Ziegler AG. Predictors of postpartum diabetes in women with gestational diabetes mellitus. Diabetes 200655 792-797.

3 Bo S, Valpreda S, Menato G, Bardelli C, Botto C, Gambino R, Rabbia C, Durazzo M, Cassader M, Massobrio M \& Pagano G. Should we consider gestational diabetes a vascular risk factor? Atherosclerosis 2007194 e72-e79.

4 Ranheim T, Haugen F, Staff AC, Braekke K, Harsem NK \& Drevon CA. Adiponectin is reduced in gestational diabetes mellitus in normal weight women. Acta Obstetricia et Gynecologica Scandinavica 200483 341-347.

5 Ategbo JM, Grissa O, Yessoufou A, Hichami A, Dramane KL, Moutairou K, Miled A, Grissa A, Jerbi M, Tabka Z \& Khan NA. Modulation of adipokines and cytokines in gestational diabetes and macrosomia. Journal of Clinical Endocrinology and Metabolism $2006914137-4143$.

6 Kinalski M, Telejko B, Kuzmicki M, Kretowski A \& Kinalska I. Tumor necrosis factor alpha system and plasma adiponectin concentration in women with gestational diabetes. Hormone and Metabolic Research 200537 450-454.
7 Lain KY, Daftary AR, Ness RB \& Roberts JM. First trimester adipocytokine concentrations and risk of developing gestational diabetes later in pregnancy. Clinical Endocrinology 200869 $407-411$.

8 Retnakaran R, Hanley AJ, Raif N, Hirning CR, Connelly PW, Sermer M, Kahn SE \& Zinman B. Adiponectin and beta cell dysfunction in gestational diabetes: pathophysiological implications. Diabetologia 200548 993-1001.

9 Qiu C, Williams MA, Vadachkoria S, Frederick IO \& Luthy DA. Increased maternal plasma leptin in early pregnancy and risk of gestational diabetes mellitus. Obstetrics and Gynecology 2004103 519-525.

10 Maghbooli Z, Hossein-Nezhad A, Rahmani M, Shafaei AR \& Larijani B. Relationship between leptin concentration and insulin resistance. Hormone and Metabolic Research 200739 903-907.

11 Festa A, Shnawa N, Krugluger W, Hopmeier P, Schernthaner G \& Haffner SM. Relative hypoleptinaemia in women with mild gestational diabetes mellitus. Diabetic Medicine 199916 656-662.

12 Yamashita H, Shao J, Ishizuka T, Klepcyk PJ, Muhlenkamp P, Qiao L, Hoggard N \& Friedman JE. Leptin administration prevents spontaneous gestational diabetes in heterozygous $\operatorname{Lepr}(\mathrm{db} /+)$ mice: effects on placental leptin and fetal growth. Endocrinology $20011422888-2897$.

$13 \mathrm{Xu} \mathrm{A}$, Wang Y, Xu JY, Stejskal D, Tam S, Zhang J, Wat NM, Wong WK \& Lam KS. Adipocyte fatty acid-binding protein is a plasma biomarker closely associated with obesity and metabolic syndrome. Clinical Chemistry 200652 405-413.

$14 \mathrm{Xu}$ A, Tso AW, Cheung BM, Wang Y, Wat NM, Fong CH, Yeung DC, Janus ED, Sham PC \& Lam KS. Circulating adipocyte-fatty acid binding protein levels predict the development of the metabolic syndrome: a 5-year prospective study. Circulation $2007 \mathbf{1 1 5}$ $1537-1543$.

15 Tso AW, Xu A, Sham PC, Wat NM, Wang Y, Fong CH, Cheung BM, Janus ED \& Lam KS. Serum adipocyte fatty acid binding protein as a new biomarker predicting the development of type 2 diabetes: a 10-year prospective study in a Chinese cohort. Diabetes Care 2007 $302667-2672$.

16 Yeung DC, Xu A, Cheung CW, Wat NM, Yau MH, Fong CH, Chau MT \& Lam KS. Serum adipocyte fatty acid-binding protein levels were independently associated with carotid atherosclerosis. Arteriosclerosis, Thrombosis, and Vascular Biology 200727 1796-1802.

17 Kautzky-Willer A, Bancher-Todesca D, Weitgasser R, Prikoszovich T, Steiner H, Shnawa N, Schernthaner G, Birnbacher R, Schneider B, Marth C, Roden M \& Lechleitner M. The impact of risk factors and more stringent diagnostic criteria of gestational diabetes on outcomes in central European women. Journal of Clinical Endocrinology and Metabolism 200893 1689-1695.

18 Fasshauer M, Bluher M, Stumvoll M, Tonessen P, Faber R \& Stepan H. Differential regulation of visfatin and adiponectin in pregnancies with normal and abnormal placental function. Clinical Endocrinology 200766 434-439.

19 Hotamisligil GS, Johnson RS, Distel RJ, Ellis R, Papaioannou VE \& Spiegelman BM. Uncoupling of obesity from insulin resistance through a targeted mutation in aP2, the adipocyte fatty acid binding protein. Science 1996274 1377-1379.

20 Uysal KT, Scheja L, Wiesbrock SM, Bonner-Weir S \& Hotamisligil GS. Improved glucose and lipid metabolism in genetically obese mice lacking aP2. Endocrinology 2000141 3388-3396.

21 Boord JB, Maeda K, Makowski L, Babaev VR, Fazio S, Linton MF \& Hotamisligil GS. Adipocyte fatty acid-binding protein, aP2, alters late atherosclerotic lesion formation in severe hypercholesterolemia. Arteriosclerosis, Thrombosis, and Vascular Biology 200222 1686-1691.

22 Makowski L, Boord JB, Maeda K, Babaev VR, Uysal KT, Morgan MA, Parker RA, Suttles J, Fazio S, Hotamisligil GS \& Linton MF. Lack of macrophage fatty-acid-binding protein aP2 protects mice deficient in apolipoprotein $\mathrm{E}$ against atherosclerosis. Nature Medicine 20017 699-705. 
23 Makowski L, Brittingham KC, Reynolds JM, Suttles J \& Hotamisligil GS. The fatty acid-binding protein, aP2, coordinates macrophage cholesterol trafficking and inflammatory activity. Macrophage expression of aP2 impacts peroxisome proliferatoractivated receptor gamma and IkappaB kinase activities. Journal of Biological Chemistry 2005280 12888-12895.

24 Furuhashi M, Tuncman G, Gorgun CZ, Makowski L, Atsumi G, Vaillancourt E, Kono K, Babaev VR, Fazio S, Linton MF, Sulsky R, Robl JA, Parker RA \& Hotamisligil GS. Treatment of diabetes and atherosclerosis by inhibiting fatty-acid-binding protein aP2. Nature 2007447 959-965.

25 Tuncman G, Erbay E, Hom X, De VI, Campos H, Rimm EB \& Hotamisligil GS. A genetic variant at the fatty acid-binding protein aP2 locus reduces the risk for hypertriglyceridemia, type 2 diabetes, and cardiovascular disease. PNAS $2006 \mathbf{1 0 3}$ 6970-6975.

26 Fisher RM, Hoffstedt J, Hotamisligil GS, Thorne A \& Ryden M. Effects of obesity and weight loss on the expression of proteins involved in fatty acid metabolism in human adipose tissue. International Journal of Obesity and Related Metabolic Disorders 200226 1379-1385.

27 Fasshauer M, Seeger J, Waldeyer T, Schrey S, Ebert T, Kratzsch J, Lossner U, Bluher M, Stumvoll M, Faber R \& Stepan H. Serum levels of the adipokine adipocyte fatty acid-binding protein are increased in preeclampsia. American Journal of Hypertension 2008 21 582-586.

28 Stejskal D \& Karpisek M. Adipocyte fatty acid binding protein in a Caucasian population: a new marker of metabolic syndrome? European Journal of Clinical Investigation 200636 621-625.
29 Haider DG, Schindler K, Bohdjalian A, Prager G, Luger A, Wolzt M \& Ludvik B. Plasma adipocyte and epidermal fatty acid binding protein is reduced after weight loss in obesity. Diabetes, Obesity and Metabolism 20079 761-763.

30 Sommer G, Ziegelmeier M, Bachmann A, Kralisch S, Lossner U, Kratzsch J, Bluher M, Stumvoll M \& Fasshauer M. Serum levels of adipocyte fatty acid binding protein are increased in chronic haemodialysis. Clinical Endocrinology, 2008 In Press DOI: 10.1111/j.1365-2265.2008.03277.x.

31 Williams MA, Qiu C, Muy-Rivera M, Vadachkoria S, Song T \& Luthy DA. Plasma adiponectin concentrations in early pregnancy and subsequent risk of gestational diabetes mellitus. Journal of Clinical Endocrinology and Metabolism $2004892306-2311$.

32 Tsai PJ, Yu CH, Hsu SP, Lee YH, Huang IT, Ho SC \& Chu CH. Maternal plasma adiponectin concentrations at 24 to 31 weeks of gestation: negative association with gestational diabetes mellitus. Nutrition 200521 1095-1099.

33 Chen D, Fang Q, Chai Y, Wang H, Huang H \& Dong M. Serum resistin in gestational diabetes mellitus and early postpartum. Clinical Endocrinology 200767 208-211.

34 Megia A, Vendrell J, Gutierrez C, Sabate M, Broch M, FernandezReal JM \& Simon I. Insulin sensitivity and resistin levels in gestational diabetes mellitus and after parturition. European Journal of Endocrinology 2008158 173-178.

Received 22 September 2008

Accepted 7 October 2008 